\title{
An Analysis of Students' Errors to Find the Result Reflection in Coordinate Plane Based On in the Newman Error Analysis Nints-Grade Students of Junior High School 2 Sampit
}

\section{Ayu Amelia Sari, Dwi Priyo Utomo, Zukhrufururrohmah}

\author{
Mathematics Education, Faculty of Teacher Training and Education, University of \\ Muhammadiyah Malang \\ E-mail: ayuamalia9@gmail.com
}

\begin{abstract}
This study aimed to determine the types and the causes of students' errors in finding the results of reflection in the field of coordinates based on the Newman problem-solving. This research used descriptive research with a quantitative approach. The data collection techniques were written test and a structured interview with the research subjects were Nints-grade students of Junior High School 2 Sampit. Based on the results of the data analysis, there were errors made by students, namely: (1) there were no mistakes in the problem of reading stage, (2) students were not able to write down the known and asked even though students understood the questions presented in the stage of understanding the problem, (3) did not change the questions into a coordinate field in the stage of transformation problem, (4) misplaced of the result reflection and miscalculating the result of reflection on the process skill stage, (5) did not writing down the answers or conclusions in the writing answers stage.
\end{abstract}

Keywords: Analysis, Coordinate Plane, Newman Error Analysis, Reflection, Students

\section{INTRODUCTION}

Education is a conscious effort by someone to become a person both in increasing their potential to be useful for themselves or others in every life. The purpose of education itself is to help students to develop their potential to become differentiators from one another in terms of knowledge, abilities, and skills that will improve the welfare of a country (Rosalina, 2016). Rosalina (2016) stated that the welfare of a country in terms of the educational system and the quality of education both in terms of the quality of educators and their students. Therefore, education is an important thing that everyone needs as a teaching or training process to achieve the goals of education itself.

Mathematics is one of the fields of study that has an important role in achieving educational goals because mathematics is an abstract science that has characteristics as a problem solver and can provide ways to model problems that exist in real life (Chambers in Tias, 2015). In line with the statement of the Ministry of National Education (2007) who states that mathematics should be given starting at the elementary school level to provide students with the ability to think rationally, structured, and critically also can work together in solving existing problems. It was proven by the time of mathematics lessons longer than others and also strengthened by the content standards for elementary and secondary education units of mathematics.

Solving a mathematical problem is not easy, this is precisely the reason why the students do not really like mathematics. One of the materials that students not interested in or like is the transformation with the reflection section (Albab, 2014). Reflection or 
shadow is one of transformation that moves each point on a field (geometry) by using the properties of the object and the axis as the mirror, so we get the result of reflected shadow. Finding the reflection shadow in the coordinate field depends on the type of axis (mirror) as well as remembering the characteristics of the shadow after it is reflected. The types of axes as the mirror are the axis $x$, axis $y$, line $y=x$, the point $o(0,0)$, line $x=h$, and line $y=k$. There are several characteristics of the shadow formed by reflection, which is: (a) the result of the shadow will have the same shape and size as the original, (b) the distance from the shadow to the mirror has the same distance as the original distance to the mirror, (c) the result of the shadow will face each other with the original. According to Morris and Paulsen (2011), some students can complete a transformation in a simple geometric form but still have difficulty in solving problems related to more complex rotations and reflections such as combinations. Besides, students have difficulty in proving a transformation result in more detail, for example, students cannot state that point $A(x, y)$ if reflected on the x-axis which produces a shadow at point $A^{\prime}(x, y)$. It is because of the teacher only explained briefly about the concepts of the changing on reflection point up to learning obstacle. It is proved by Morris and Paulsen (2011), the researchers tried to observe at SMP Negeri 2 Sampit and it turned out that the problem was also experienced by students who often made mistakes in looking for the results of the reflection shadows in the coordinates.

Error analysis is an activity of investigating, deciphering, and tracing an error to find out the type of error and the causes. According to Watson in Nurkhimah (2016), the categories of errors often occur by the students which include the data obtained from the field that are incorrect, the missing data, no conclusions drawn, inappropriate responses, and the problems in the skill stage so need to be analyzed in order to get an illustration (picture) about the weaknesses of students to be tested.

The purpose of analyzing students' errors are include: (1) to find out the mistakes that occur when completing math problems, (2) to help the teachers know about the students' understanding of the subject matter, (3) to evaluate the extent of students' understanding of the subject matter that has been taught, (4) as a benchmark in applying appropriate learning models and methods to avoid mistakes in learning (Nurkhimah, 2016).

There are two causes, which make the student made mistakes in solving mathematics problem namely, the concepts mistakes and the procedurals mistakes (Sahriah, 2013). The concept mistakes are in interpreting vocabulary, design, and beliefs. The indicators of conceptual mistakes based on Kastolan in Sahriah (2013) which are defining the pattern, inappropriate pattern in some conditions to use its pattern, do not write down the pattern in solving the problems. While procedural mistakes are the mistakes in preparing the step of answering the questions. The indicators of procedural mistakes based on Kastolan are incomplete steps in solving problems and unable to sort the steps properly to solve the problems.

One of the methods in analyzing errors is by using the solving problems of Newman. In the Newman solving problem stage not much different from the Polya solving problems stage, it's just the step of Polya solving problem there is no reading problem step even though it is an initial factor in determining students' ability to solve mathematical problems. Newman describing the steps in solving the problems namely, (1) read the problem which is when the students read the question will be processed the question that has been read become understand the concepts, (2) understanding the problems (comprehension) in which the students can understand the question also 
showing the ideas of the problem like what have been known and asked, (3) problem transformation where the students change the question into mathematical solving forms also defining the procedural used to solve the problems, (4) skill process where the students answered the question based on the mathematical procedural which have been made in the transformation problem stage, and (5) writing down the answers (encoding) which is the students write down the answer which has been asked appropriately (Amalia, 2017).

In this study, the researcher identified student errors based on Newman with the following indicators:

Table 1: Student Error Indicators Based on Newman

\begin{tabular}{ll}
\hline \multicolumn{1}{c}{ Error Phase } & \multicolumn{1}{c}{ Indicators } \\
\hline Errors in reading problems & $\begin{array}{l}\text { Students incorrectly read symbols or interpret } \\
\text { important information in problems }\end{array}$ \\
\hline $\begin{array}{l}\text { Error in understanding } \\
\text { problem }\end{array}$ & $\begin{array}{l}\text { Students do not write and explain knowing what is } \\
\text { known and asked the problem. } \\
\text { Error forming information so that it cannot complete } \\
\text { the next process. }\end{array}$ \\
\hline $\begin{array}{l}\text { Error in processing } \\
\text { transformation }\end{array}$ & $\begin{array}{l}\text { Students cannot change questions into the proper } \\
\text { form of mathematical operations. } \\
\text { Students incorrectly recognize a mathematical } \\
\text { operation or series of operations. }\end{array}$ \\
\hline Error in processing the skills & $\begin{array}{l}\text { Students are wrong in the process or algorithm to } \\
\text { solve problems. } \\
\text { Students cannot solve the problem even though they } \\
\text { can determine the procedure correctly. }\end{array}$ \\
\hline & $\begin{array}{l}\text { Students do not write the final answer requested on } \\
\text { the problem. } \\
\text { Students cannot deduce answers according to } \\
\text { mathematical sentences. }\end{array}$ \\
\hline
\end{tabular}

Source: (Singh, 2010)

Apart from the five stages of errors that have been raised by Newman, Clements (in Rindayana, 2012) states that there are two indicators of errors that can influence the occurrence of Newman errors, namely carelessness and motivation, which means that both of these errors can occur at all stages. to Newman.

Based on the background, the researcher is interested in raising the title of the study: "Analysis of Student Errors in Finding the Results of the Reflection of Transformation Reflections in the Coordinating Field based on the resolution of Newman errors in Class IX of SMP Negeri 2 Sampit". Based on the explanation that has been delivered, the problem formulation in this research is how the analysis of students' mistakes in looking for the results of the reflection of the transformation in the field of coordinates in class IX SMP Negeri 2 Sampit. Based on the formulation of the problem, the goal to be achieved is to find out the types and causes of students' mistakes in searching for the reflection results of the transformation in the coordinate plane in class IX of SMP Negeri 2 Sampit. 


\section{RESEARCH METHODS}

In this study, the approach used is a qualitative approach to the type of research used is descriptive research. This research was conducted at SMP Negeri 2 Sampit in the even school year 2018/2019. The data collected in the study are data from the results of written tests and interviews about looking for reflection shadow results in the coordinate plane given to grade IX students in the school. Researchers used a 6 item description problem and were done in 60 minutes about finding the results of the reflection image in the coordinate plane. Furthermore, researchers grouped data based on student error indicators to make it easier to conclude. After a written test conducted, the researcher conducts an interview to help further describe the students' mistakes about looking for the results of the reflection image in the coordinate plane to ascertain the mistakes made by students. The study was conducted in a structured manner and was conducted on six students drawn from two students with the highest grades, two students with a median score, and two students with the lowest grades based on written results.

Technical data analysis by (1) Data reduction stage: (a) correcting and scoring student answer sheets to determine students who were subjected to interviews, (b) interview results are simplified into descriptive form, (2) Presenting data that has been categorized in types the same mistakes in order to give a clearer picture of the mistakes made by students. The procedure is as follows: (a) analyzing written test errors, (b) grouping students who make the same mistakes based on problem solving Newman, (c) conducting interviews with 6 students who have been selected (d) presenting complete data and analysis so that they can be used in drawing conclusions, (3) Drawing conclusions from the data that has been analyzed namely regarding the errors of students in looking for the results of reflection in the field of coordinates by comparing the analysis of the results of work and student interviews.

\section{RESULTS AND DISCUSSION}

Following is the explanation of the results of the analysis of the mistakes made by students based on solving the problem of Newman after the written test and interview as follows:

a. The problem reading stage

All students have no errors in reading symbols or important information contained in the questions.

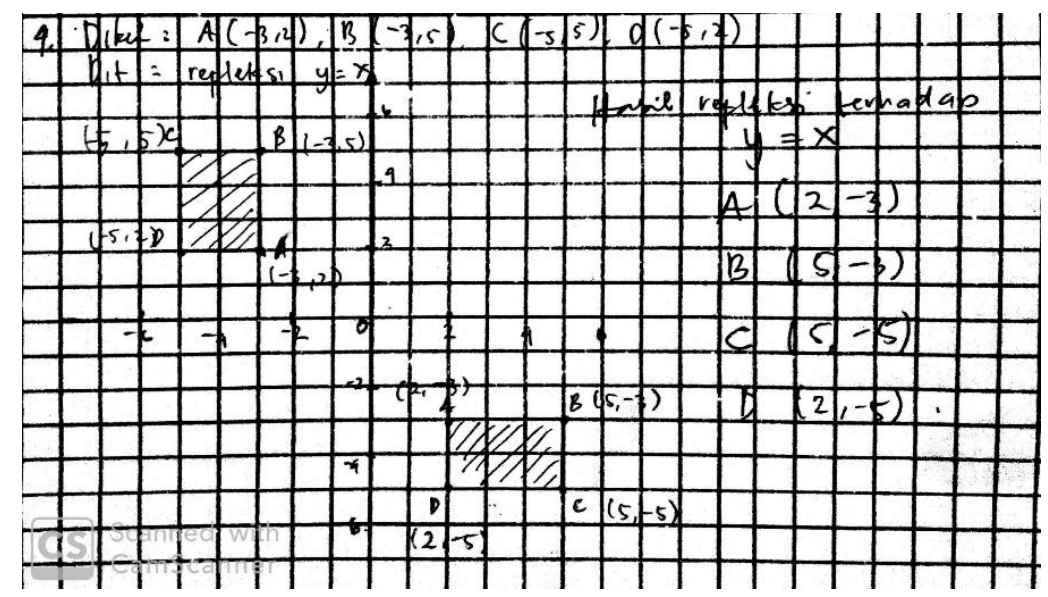

Figure 1 The result of students' written tests number 4 
Figure 1 is the results of students' written tests that show students did not make mistakes in the reading stage of the problem because in the work of students did not make mistakes writing symbols or mistakes in retrieving important information to solve the problem. It can be seen that students are correct in writing coordinate points on problems like $A(-3,2)$.

b. Stage of understanding the problem

At this stage, there are several factors that cause students to make mistakes, including: (a) students do not write what is known and asked about the problem.

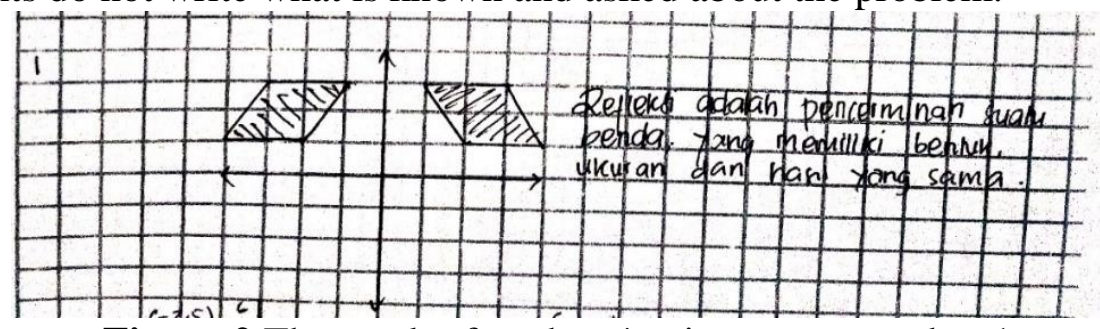

Figure 2 The result of students' written tests number 1

Figure 2 shows the mistakes made by students in the stage of understanding the problem, clearly seen students do not write what is known and asked to the problem even though during the interview students know what is known and asked about the problem. That is because students are not accustomed to writing what is known and asked and indicated as carelessness because they are not careful in reading the instructions of existing questions (Clements in Rindayana, 2012).

(b) in question number 1 , some students are only able to write two of the three that are known in the problem.

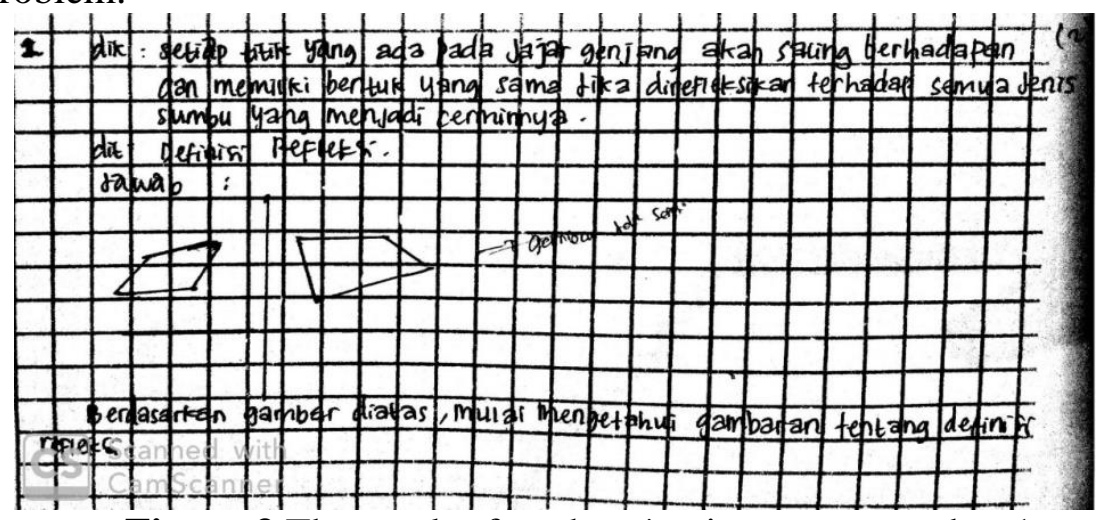

Figure 3 The result of students' written tests number 1

Figure 3 shows the student's mistake, which only mentioned two of the three statements in the problem, namely the student did not write the statement of the distance of the two lines to the same mirror. This also results in students' transformation not being precise in depicting illustrations related to the questions in the questions.

(c) in question number 2, some students did not draw a known illustration.

\section{2-) diki gahbat segrtga Skut fiku Gand berhadaban}

Figure 4 The result of students' written tests number 2

Figure 4 shows students' mistakes because they did not illustrate known illustrations in the problem. This can be caused by two factors due to the lack of enthusiasm or motivation of students in working on students so that the students are in a 
hurry and are not careful enough to think that illustrations do not need to be illustrated and can be arranged together with words. This is in line with research conducted by Clement (in Rindayana, 2012) which states that lack of motivation and lack of accuracy can be a factor in students' mistakes.

\section{c. Problem transformation stage}

At this stage, almost all students make a transformation error by not changing the questions in the form of coordinate fields. Here are some factors that cause students to make these mistakes, among others: (a) in problem number 2, some students misinterpret the illustrations in the questions.

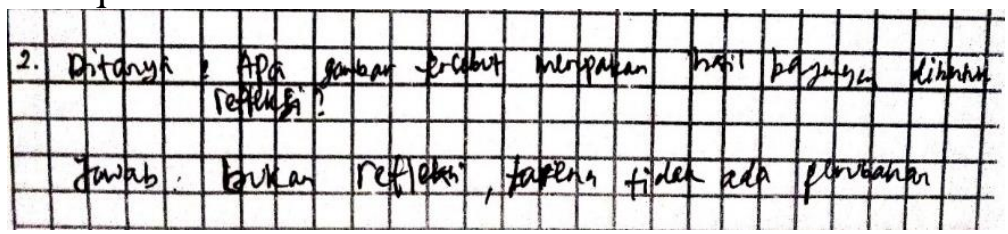

Figure 5 The result of students' written tests number 2

Figure 5 shows students wrong in interpreting the illustrations in the problem even though the illustrations are a reflection.

(b) Students incorrectly place the known coordinate points.

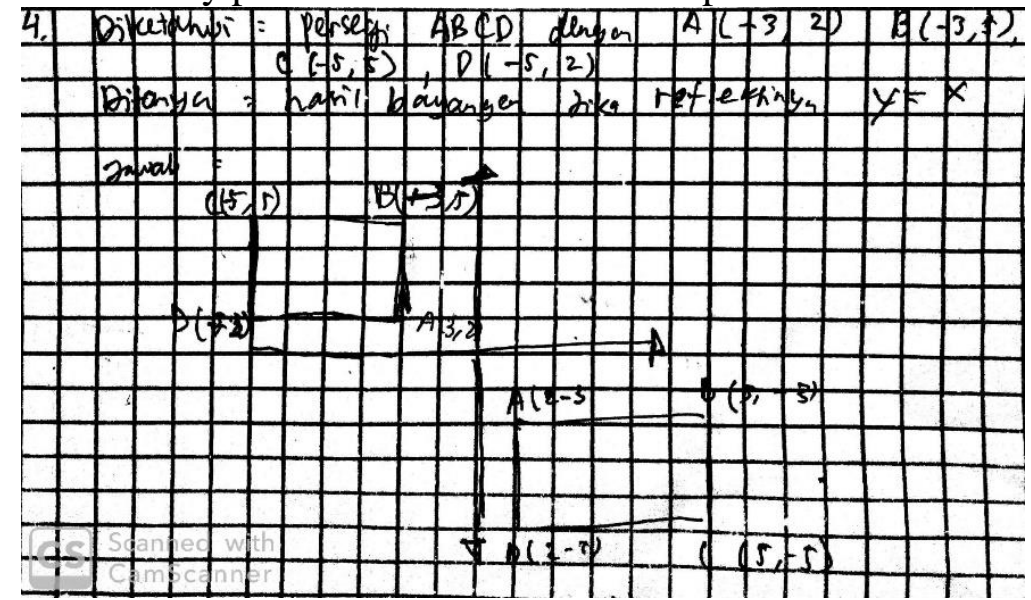

Figure 6 The result of students' written tests number 4

Figure 6 shows students wrong in placing the known coordinate points on the problem even though in writing the coordinate points are correct. This can be caused by two factors due to lack of enthusiasm or motivation of students in working on students so that in a hurry in placing the coordinates. This is in line with research conducted by Clement (in Rindayana, 2012) which states that lack of motivation can be a factor in student error.

(c) In question number 6, students are only able to transform one of the two statements into the shape of the coordinate plane. 


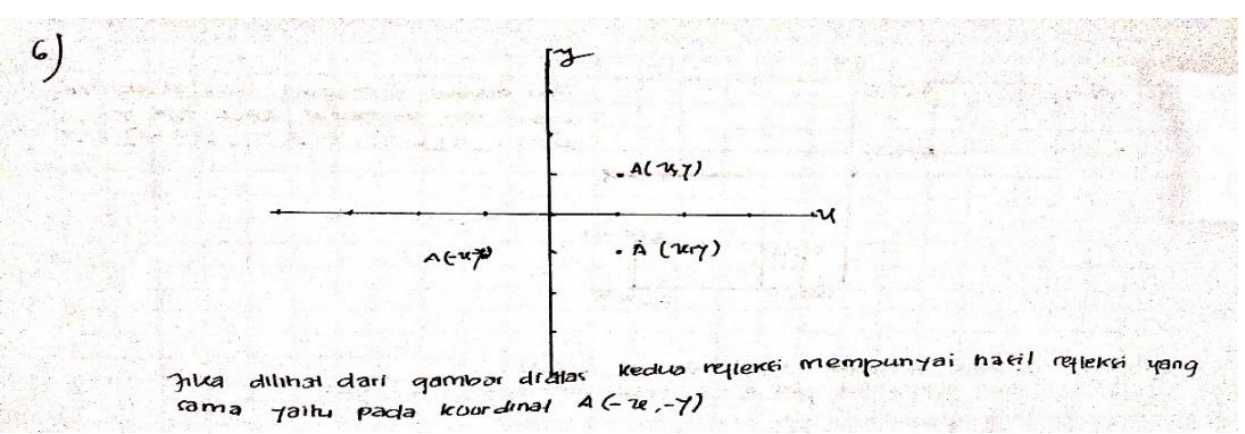

Figure 7 The result of students' written tests number 6

Figure 7 shows students are only able to make one of the two coordinate fields in the statement of the problem that is the result of reflection on the $\mathrm{x}$-axis and continued with a reflection on the $y$ - axis (repeated reflection).

(d) Students do not transform questions into the form of coordinate fields.

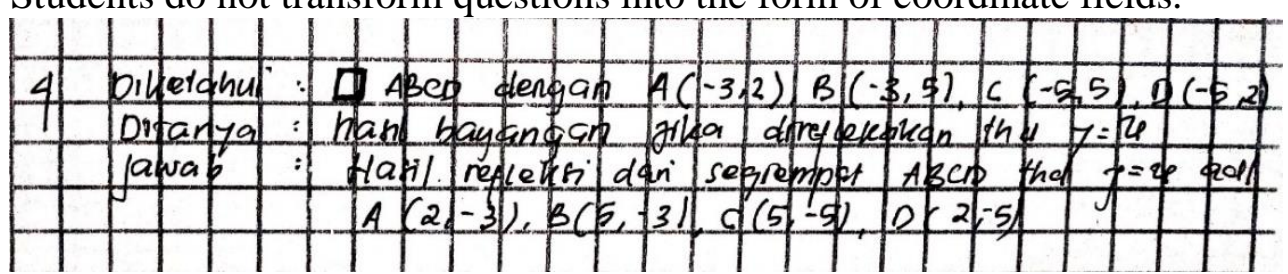

Figure 8 The result of students' written tests number 4

Figure 8 shows students not transforming questions into the form of coordinate fields. Then the errors in the transformation stage of this problem can be categorized into the lack of motivation of students because they already know the answer so that they no longer need to change it into the form of coordinates and carelessness because they are not careful in reading the workmanship instructions. This is in line with research conducted by Clement (in Rindayana, 2012) that motivation and carelessness can be a factor in the occurrence of student mistakes.

\section{d. Process skills stage}

In this stage, almost all students made mistakes because students also made mistakes at the stage of problem transformation. As for some other factors that cause mistakes made at the process skills stage, there are (a) wrong in writing the results of reflection images.

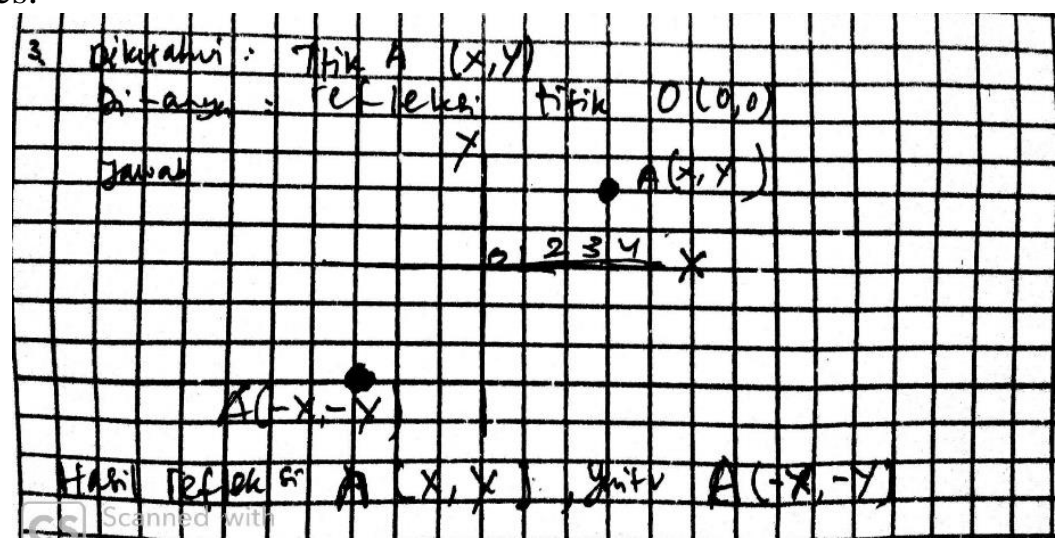

Figure 9 The result of students' written tests number 3 
Figure 9 shows students made mistake in placing the coordinates of the results of the reflection of $A(x, y)$ because the distance between the mirror to the original point is not the same as the distance between the mirror to the reflection image.

(b) In problem number 2, students were only able to write two of the three properties of objects if reflected.

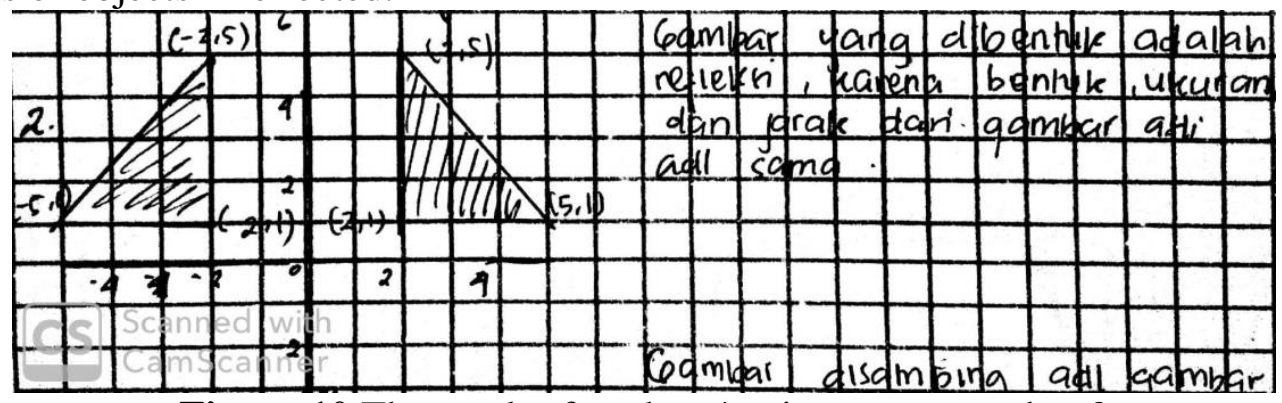

Figure 10 The result of students' written tests number 2

Figure 10 shows students can only write two of the three properties of objects if they are reflected namely the shape, size of the objects that are reflected the same and the distance of the original image of the mirror, and the distance of the result of reflection to the mirror are the same. Students do not write one more object if they are reflected, that is, objects will face each other if they are reflected.

(c) In question number 5, some students only completed one of the two results of reflection (repeated).

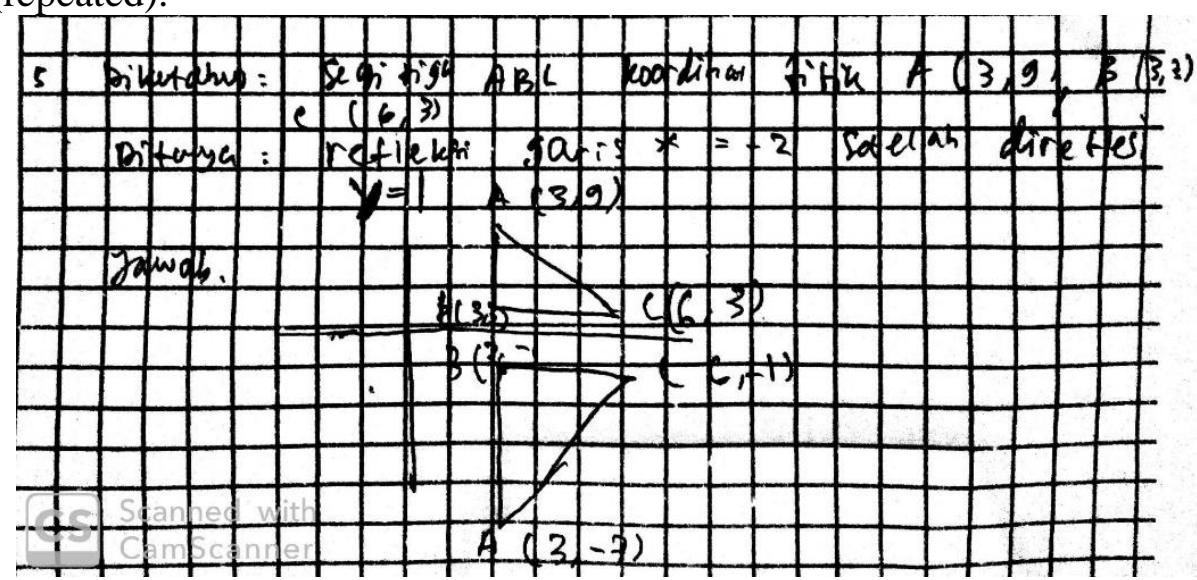

Figure 11 The result of students' written tests number 5

Figure 11 shows students were able to complete one reflection ie to the line $y=1$ and unable to continue the next reflection.

(d) In problem number 6, students only completed one of the two coordinate fields related to the results of reflection. 


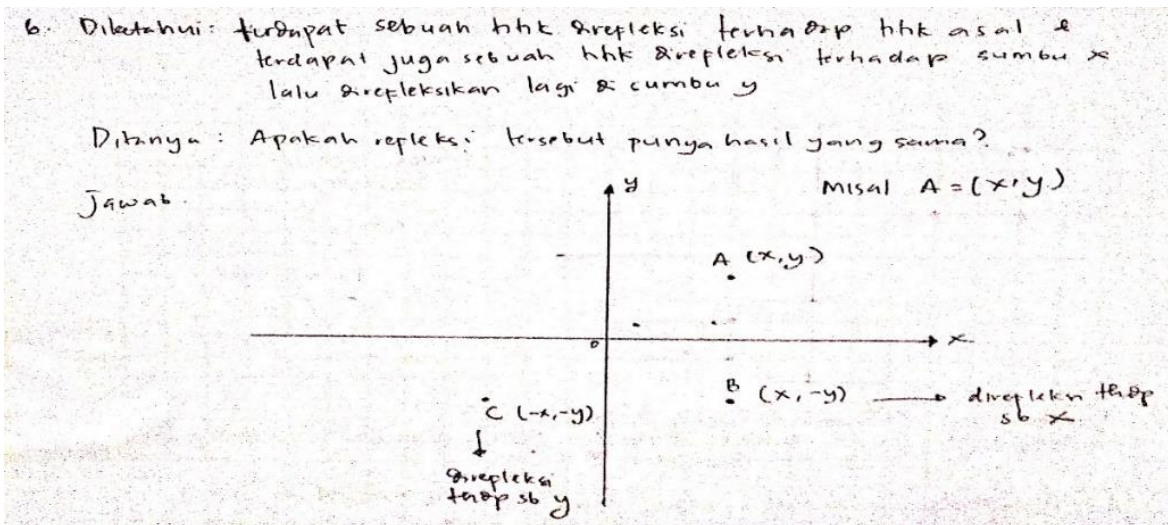

Figure 12 The result of students' written tests number 6

Figure 12 shows students did not complete one plane of the coordinate reflection which towards the origin $O(0,0)$. This is because in question number 3 also looks for the result of the shadow with respect to the origin point $O(0,0)$ with any point so that students who have solved problem number 3 correctly already know the result of the shadow to the point of origin which is $(-x,-y)$.

\section{e. The stage of writing answers}

At this stage, almost none of the students made mistakes because they could write the answers correctly. On the other hand, some students have not written answers correctly. As for some of the causes of errors as follows: (a) in question number 6, some students did not write the final answer in full.

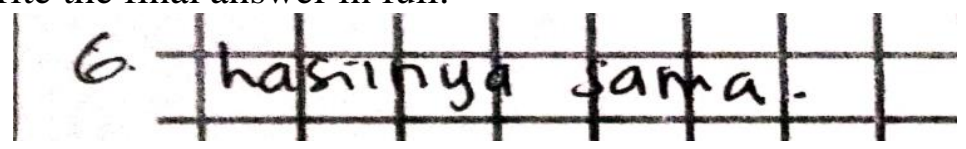

Figure 13 The result of students' written tests number 6

Figure 13 shows the incomplete answers of students. If the results are the same, then the particular coordinates are located at the two coordinate fields if they have the same reflection results. In question number 6 the results of the reflection of the two coordinate fields are $(-x,-y)$.

(b) Students did not write the final answer. 


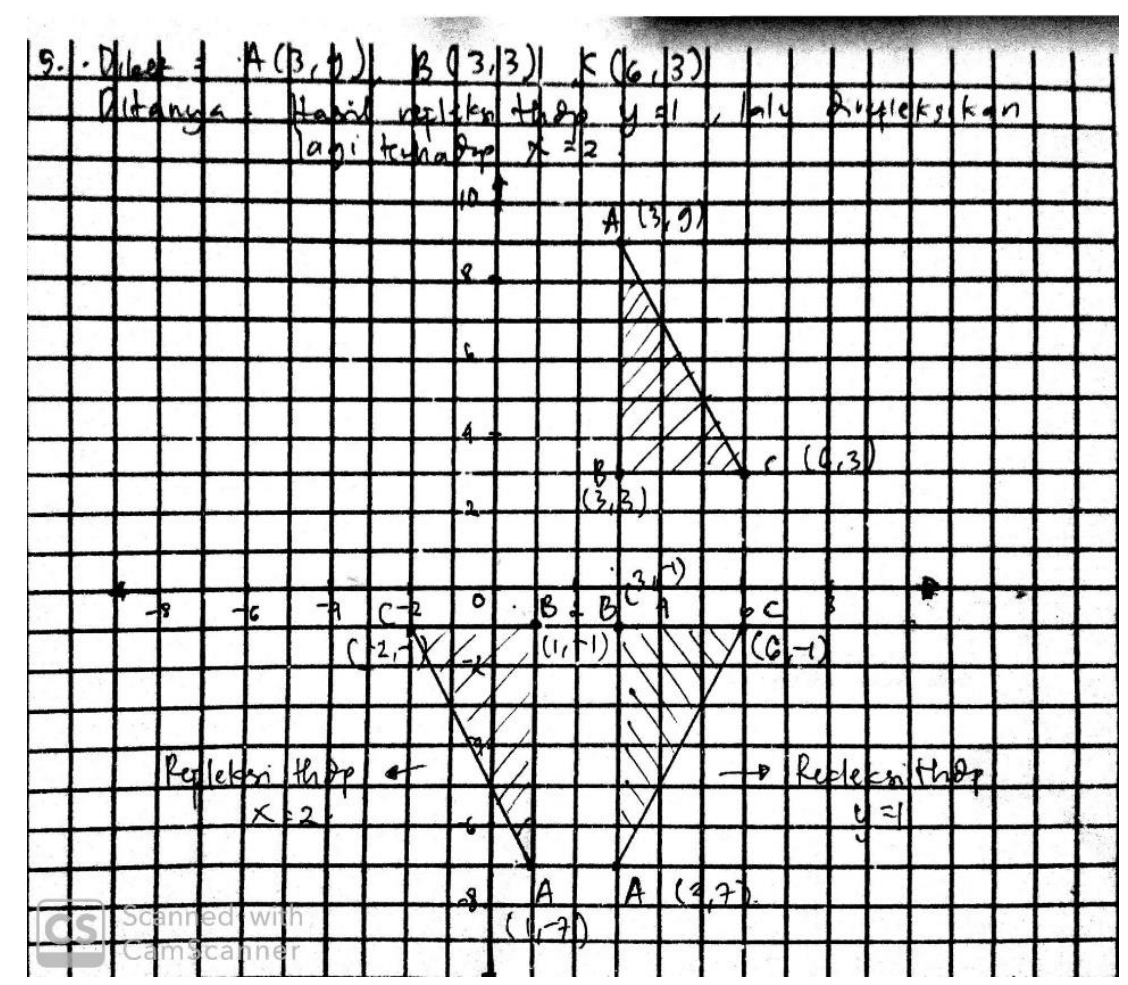

Figure 14 The result of students' written tests number 5

Figure 14 shows students were not writing down the results of the answers after completing the questions. This can be caused by a lack of student motivation to write answers because they have been answered at the process skills stage (Clement in Rindayana, 2012).

Based on the results obtained by the researcher, the biggest error factor made by students was the lack of understanding of the material about looking for reflection results in the coordinate plane, both by definition and the nature of objects after being reflected which was caused by several factors: (1) student handbooks contain too brief material so students tend to practice and practice working on the problems, (2) The teacher explained the reflection too quickly because the transformation has several sub-chapters which still need to be explained again to students, (3) Lack of time for students to work on problems so that researchers and teachers do not know whether students understand the reflection material well, (4) Students often had less of enthusiasm or motivation and also sometimes being not careful in working on problems. So, researchers and teachers sometimes misinterpret these students into not understanding the material.

This is in line with several studies which discuss error solving based on Newman, namely: (1) Amalia's research (2017) states that the cause of errors is the lack of accuracy of students in working on problems due to rush, not understanding the questions properly so that in writing what is known and asked the questions students tend not to write it down. Also, lack of time written test work so that it becomes the obstacle of the analysis of errors because researchers cannot know whether students master the material under study, (2) Islamiyah research (2017) which mentions the biggest error factor made by students is at the stage of understanding the problem with a percentage of $55.65 \%$ including students' mistakes in writing incorrect, precise but incomplete answers, not writing so that it is directly at the stage of problem transformation. However, at the stage of reading problems there is research that is not in 
line with research Oktaviana (2017) states that there are errors in reading problems with a percentage of $24 \%$ this is because students do not know the important information contained in the problem so that confusion when working and cannot proceed to the stage next.

\section{CONCLUSION}

Based on the exposure to the results and discussion of the study, a conclusion is made about the mistakes made by students in searching for reflection results based on the completion of the Newman: (1) there are no errors in the problem reading stage, (2) students are not able to write the known and asked questions even though students understand the questions presented at the stage of understanding the problem, (3) do not change the problem into a coordinate plane at the problem transformation stage, (4) incorrectly place the results of the reflection shadow and do the calculation of the reflection results at the process skills stage, (5) no write answers or conclusions at the stage of writing the answers. the cause of students' mistakes is carelessness due to inaccuracy, lack of motivation in working on problems, lack of time working on questions, little material contained in the student handbook, and the teacher is too fast in explaining reflection due to transformation has several sub-chapters that still need to be explained again to students.

\section{REFERENCES}

Agusta I. Teknik Pengumpulan dan Analisis Data Kualitatif. Jurnal Studi Komunikasi Dan Media. 2014; 2(1998): 1-11.

Albab IU, Hartono Y, Darmawijoyo D. Kemajuan belajar siswa pada geometri transformasi menggunakan aktivitas refleksi geometri. Jurnal Cakrawala Pendidikan. 2014; 33(3): 338-348

Amalia SR. Analisis Kesalahan Berdasarkan Prosedur Newman Dalam Menyelesaikan Soal Cerita Ditinjau Dari Gaya Kognitif Mahasiswa. Aksioma. 2017; 8(1):17.

Badan Penelitian dan Pengembangan Pusat Kurikulum. Kajian Kebijakan Kurikulum Mata Pelajaran Matematika. Jakarta:Depdiknas, 2007.

Gunawan I. Metode Penelitian Kualitatif. Malang: Universitas Negeri Malang, 2016.

Guven B. Using dynamic geometry software to improve eight grade students' understanding of transformation geometry. Australasian Journal of Educational Technology. 2012; 28(2): 364-382.

H Sumarjo. Analisi Data Kualitatif dalam Penelitian Teknik Arsitektur. Inersia. 2010; VI(1): 41-51.

Hartati S, Hartono Y. Belajar Pencerminan Dengan Menggunakan Permainan BomBoman Di Kelas VII. Jurnal Review Pembelajaran Matematika. 2007; 3(1): 4961.

Iryana, Kawasati, R. Teknik Pengumpulan Data Metode Kualitatif. Al Riwayah Jurnal Kependidikan. 1990; 4(1); 56-79.

Islamiyah, Anna Citra. Analisis Kesalahan Siswa SMP pada Penyelesaian Masalah Sistem Persamaan Linier Dua Variabel. Jurnal Didaktik Matematika. 2018; 5(1): 66-76

Komarudin. Analisis Kesalahan Pemecahan Masalah Matematika pada Materi Peluang Berdasarkan High Order Thinking. Jurnal Pendidikan, Komunikasi Dan Pemikiran Hukum Islam. 2016; 8(1): 202-217. 
Kurniasih MD, Handayani I. Tangkas Geometri Transformasi. jakarta: Universitas Muhammadiyah Prof.Dr.Hamka, 2017.

Lipianto D, Budiarto MT. Analisis kesalahan siswa dalam menyelesakan soal yang berhubungan dengan persegi dan persegipanjang berdasarkan taksonomi solo plus pada kelas vii. Mathedunesa. 2013; 2(1): 1-8.

Nilamsari, S. 2014. Memahami Studi Dokumen Dalam Penelitian Kualitatif. Wacana, 12(2), 5 .

Nurhikmah S, Febian. Analisis Kesalahan Siswa dalam Menyelesaikan Permasalahan Integral Tak Tentu. Jurnal Pemikiran Dan Penelitian Pendidikan. 2016; 14(2): 218-237.

Oktaviana D. Analisis Tipe Kesalahan Berdasarkan Teori Newman dalam Menyelesaikan Soal Cerita pada Mata Kuliah Matematika Diskrit. Edusains: Jurnal Pendidikan Sains \& Matematika. 2017; 5(2): 1-11.

Pusat Bahasa Departemen Pendidikan Nasional. Kamus Besar Bahasa Indonesia. Jakarta: Depdiknas, 2008.

Rahardjo M. Metode Pengumpulan Data Penelitian Kualitatif. Malang: Universitas Islam Negeri Malang, 2009.

Rahmat SP. Penelitian Kualitatif. Equilibrium.2019; 4(9):1-8.

Rini YS. Pendidikan: Hakekat, Tujuan dan Proses. Jogyakarta: Pendidikan Dan Seni Universitas Negeri Jogyakarta, 2013.

Rosarina G, Sudin A, Sujana A. Penerapan Model Discovery Learning Untuk Meningkatkan Hasil Belajar Siswa Pada Materi Perubahan Wujud Benda. Jurnal Pena Ilmiah. 2016; 1(1): 371-380.

Sahriah S, Muksar M, Lestari T. Analisis Kesalahan Siswa dalam Menyelesaikan Soal Matematika Materi Operasi Pecahan Bentuk Aljabar Kelas VIII SMP Negeri 2 Malang. Online Universitas Negeri Malang. 2012; 1(1):1.

Satoto S, Sutarto H, Pujiastuti E. Analisis Kesalahan Hasil Belajar Siswa dalam Menyelesaikan Soal dengan Prosedur Newman. Unnes Journal of Mathematics Education Research. 2013;2(1):76-83.

Subchan, Winarni, Dkk. Buku Guru Matematika. Jakarta: Kemendikbud, 2010.

Suryana. Metodologi Penelitian: Metodologi Penelitian Model Prakatis Penelitian Kuantitatif dan Kualitatif. Jakarta: Universitas Pendidikan Indonesia, 2010.

Suryana, A. Tahap-tahap Penelitian Kualitatif. Jakarta: Universitas Pendidikan Indonesia, 2017 